Para enlazar con este artículo / To link to this article:

http://dx.doi.org/10.6035/MonTI.2018.10.7

Para citar este artículo / To cite this article:

Muñoz-Miquel, Ana; Pilar Ezpeleta-Piorno \& Paula Saiz-Hontangas. (2018) "Intralingual translation in healthcare settings: strategies and proposals for medical translator training." In: Montalt, Vicent; Karen Zethsen \& Wioleta Karwacka (eds.) 2018. Retos actuales y tendencias emergentes en traducción médica / Current challenges and emerging trends in medical translation. MonTI 10, pp. 177-204.

\title{
INTRALINGUAL TRANSLATION IN HEALTHCARE SETTINGS: STRATEGIES AND PROPOSALS FOR MEDICAL TRANSLATOR TRAINING ${ }^{1}$
}

\author{
Ana Muñoz-Miquel \\ munoza@uji.es \\ Universitat Jaume I \\ Pilar Ezpeleta-Piorno \\ ezpeleta@uji.es \\ Universitat Jaume I \\ Paula Saiz-Hontangas \\ psaiz@uji.es \\ Universitat Jaume I
}

\begin{abstract}
Recent studies have shown that medical translators are increasingly called upon to write patient information materials by reformulating specialised texts, either inter- or intralingually (Muñoz-Miquel 2014, 2016a). This activity requires applying a series of intralingual translation skills, which, however, are rarely addressed in medical translator training programmes. This paper aims to contribute to filling this gap by putting forward a proposal designed to help translators acquire these skills. For this purpose, we take as a starting point an empirical study carried out by the GENTT Research Group (Universitat Jaume I, Spain) in which a series of intralingual strategies were used to make real fact sheets for cancer patients more comprehensible and effective for
\end{abstract}

1. This article is part of the research projects: "Improving interlinguistic and intercultural clinical communication: new methodologies for training healthcare professionals" (20162018) (FFI2015-67427-P), funded by the Spanish Ministry of Economy and Innovation (MINECO); and "Study of Informed Consent and Medical Consultation in the Spanish and British contexts: new methodologies for improving clinical communication" (20162018) (P1.1B2015-73) funded by the University Jaume I (Spain). 
these readers. After describing the strategies, which were validated by the patients, we offer a training proposal aimed at fostering medical translators' skills for dealing with this type of intralingual translation.

\section{Resumen}

Según estudios recientes, a los traductores médicos se les requiere redactar textos dirigidos a pacientes a partir de la reformulación, ya sea inter o intralingüística, de textos especializados (Muñoz-Miquel 2014, 2016a). Para ello, es necesario aplicar una serie de estrategias de traducción intralingüística, que, sin embargo, apenas se trabajan en los programas de formación traductores médicos. Este artículo pretende contribuir a llenar este vacío mediante una propuesta orientada a su adquisición. Para ello nos basamos en los resultados de un estudio empírico llevado a cabo por el grupo GENTT (Universitat Jaume I) en el que se mejoró la comprensibilidad de una serie de folletos para pacientes oncológicos mediante el uso de estrategias de traducción intralingüística. Tras describir dichas estrategias, que fueron validadas por los pacientes, proponemos una serie de actividades didácticas con el objetivo de fomentar la habilidad de los traductores para enfrentarse a este tipo de traducciones.

Keywords: Intralingual translation. Comprehensibility. Medical translator training. Fact sheets for patients. Textual genre.

Palabras clave: Traducción intralingüística. Comprensibilidad. Formación de traductores médicos. Guías para pacientes. Género textual. 


\section{Introduction}

The democratisation of access to information (Muñoz-Miquel 2012: 187) and the development of new technologies (Campos 2013: 48) have made a large quantity of medical information resources available to patients, and this has stimulated their interest in playing a more active part in their own healthcare. Consequently, the doctor-patient relationship has changed from being eminently asymmetrical and paternalistic to involving greater engagement of patients in decision-making on the management of their health (Arrighi, Jovell \& Navarro 2010: 370).

The advent of what is known as patient-centred care has thus increased the need to have medical information written in a form that is comprehensible to a wide, heterogeneous, non-specialist audience and also "takes account of their specific situation, needs, values and expectations" (Navarro 2014: 86). We are dealing, therefore, with information that aims to bridge the gap between two different knowledge and discourse communities (Montalt \& Shuttleworth 2012: 15; García-Izquierdo \& Montalt 2013: 40), namely medical specialists and lay readers.

An increasing number of publications written for specialists are currently being intralingually recontextualised — entailing a "move to a target context with different participants, purposes, expectations, values, etc." (Montalt $\&$ Shuttleworth 2012: 16) — and reformulated — involving "a textual operation of rearranging and reexpressing the content in a different target text" (Montalt \& Shuttleworth 2012: 16) - to meet the needs of a non-specialist audience. We can find examples in the consumer version provided online by the prestigious Merck Manual, where content related to diseases, diagnostic procedures, health news, etc. is explained so that the general public can understand it. Another example is the fact sheets for patients (FSPs) published by the European Society for Medical Oncology (ESMO). These are derived from clinical practice guidelines, a genre aimed at medical professionals based on a systematic review of clinical evidence to support decision-making processes in patient care. Annals of Internal Medicine's summaries for patients, which are brief, non-technical summaries of studies and clinical guidelines published 
in that journal, are another initiative to "help patients better understand the complicated and often mystifying language of modern medicine" (see http:// annals.org/aim/pages/patient-information).

To the best of our knowledge, recontextualisations and reformulations of this kind, or expert-to-lay intralingual adaptations, tend to be done mostly by medical professionals. Indeed, those who appear as authors of the ESMO's FSPs or of the articles published in the Merck Manual consumer version, for example, are medical practitioners or doctors of medicine. However, this often causes considerable problems for medical professionals, who usually find it difficult to write about their field in layman terms (Zethsen 2009: 809). Albin made this clear in 1998 (1998: 117):

Health-care providers, in an effort to save time and assist patients, produce instructional medical texts in-house, sometimes without any real written communication skills. When non-writers write instructional texts, essential background information and procedural steps may be omitted because they seem obvious to the author; data may be reduced to such an extent that the information is rendered incomprehensible to the lay person; technical terms may be left undefined or, in an effort to reach patients who are not highly literate, substituted with jargon or imprecise lay terms. As a result, countless hours are wasted every year at both ends of the writing/reading communication continuum producing documents which fail to convey information.

The study conducted by Jensen and Zethsen (2012) produced similar results, in that it shows that doctors and pharmacists who translate patient information leaflets for medicines from English to Danish have more difficulties than trained translators in adapting to the reader's register and prior knowledge. They introduce more elements that impede readability into their target texts (Askehave \& Zethsen 2000, 2002), such as nominalisations and terms of Greek or Latin origin, even when a more comprehensible alternative exists in Danish. Even though their study, as we can see, focuses not on producing expert-to-lay intralingual adaptations but on "traditional" interlingual translations, it makes it clear that doctors' and pharmacists' extensive medical knowledge represents a problem when it comes to adapting to the reader's needs, as they have to "struggle to distinguish between their own knowledge and that of the receiver" (Jensen \& Zethsen 2012: 45).

Although, as we have already said, those who take on the task of producing expert-to-lay intralingual adaptations are mostly medical professionals, recent studies show that this trend is beginning to change. An empirical study (Muñoz-Miquel 2014, 2016a) in which 187 English-to-Spanish medical translators were surveyed showed that $17 \%$ of them carry out such intralingual adaptations as part of their professional activity, such as turning scientific 
articles or summaries of product characteristics (SPCs) into FSPs. Although this is not a very high percentage, it shows that the range of tasks that can be performed by trained translators is beginning to expand. However, do medical translators know how to write texts that prove useful in adapting to patients' and lay readers' needs? Do they receive specific training to enable them to carry out these expert-to-lay intralingual adaptations successfully?

In our view, producing these adaptations requires adopting a series of strategies that are used not in what is traditionally referred to as "translation proper" (Jakobson 1959/2000: 114), that is, equifunctional translation between different languages, but in intralingual translation (Zethsen 2007, 2009; Muñoz-Miquel 2012), also known as heterofunctional translation (Nord 2009), intergeneric translation (Askehave \& Zethsen 2001; García-Izquierdo \& Montalt 2013), rewording (Jakobson 1959/2000) or genre shift (Montalt \& González 2007; Ezpeleta-Piorno 2012). Although there are still some scholars that do not feel comfortable with a broad, inclusive definition of translation (Zethsen 2009: 798; Zethsen \& Hill-Madsen 2016), it is increasingly agreed within the academic community that the translators' responsibilities go well beyond the very notion of interlingual translation. We agree with authors such as Schäffner (1999), Zethsen (2009) and Zethsen and Hill-Madsen (2016), who argue for the inclusion of intralingual translation on the map of Translation Studies.

The skills used to carry out these intralingual translations in the medical field have scarcely been addressed, except in a few studies such as those of Askehave and Zethsen (2001), Montalt and González (2007), Ezpeleta-Piorno (2012), Muñoz-Miquel (2012) or Hill-Madsen (2014). Most of these focus on describing the strategies used in a corpus of popularising genres "intergenerically derived" (Askehave \& Kastberg 2001: 491) from others of a more specialised nature. As we can see, in addition to the fact that the literature on the subject is not plentiful, there is a predominance of descriptive studies, but not of research that validates the strategies applied to particular texts, using lay readers or real patients to test their effectiveness and incorporate the perspective of those who will be the end users of the texts (Saiz-Hontangas 2015).

Nor are we aware of any initiatives that carry these strategies over to the field of training medical translators. Indeed, in Spain, at least, they receive hardly any preparation for tackling intralingual translation jobs in response to increasingly varied communication needs. This is clear from an empirical study (Muñoz-Miquel 2016b) which analyses the competences taught in master's degree courses on medical translation in Spain: only two of the 15 courses available include tasks that deal with these strategies. 
In the light of all the points noted so far, this study is based on the following premises:

- Expert-to-lay adaptations are intralingual translations.

- Advances in research (should) feed into advances in education and in training programmes.

- Translation programmes have to adapt to the rapidly changing market.

- The tasks that a medical translator will face are diversifying.

- Medical translators can improve their professional performance if they receive specific training in intralingual translation skills.

Therefore, in view of the lack of training provision for acquiring the competences needed to carry out intralingual translations that make specialised knowledge accessible to patients and the general public, this paper aims to contribute to filling this gap by putting forward a teaching proposal designed to help translators acquire intralingual translation skills. As we shall see in detail in the following sections, one of the most interesting aspects of our proposal is that it is based on the results of a case study which used patients to validate a series of intralingual translation strategies applied to real texts. In this regard, in line with the arguments stated by Kim (2012), we believe that research on (intralingual) translation in real professional contexts can benefit the design and planning of training for specialised translators.

This article is structured as follows: section 2 describes the case study which tested a series of intralingual translation strategies with real patients; section 3 presents the teaching proposal, with examples of specific activities that could be performed; and finally, section 4 summarises the main conclusions of the study, as well as various applications and future lines of research.

\section{Materials and methods}

In this section we explain the case study which we have used as a basis for formulating the teaching proposal to be described in detail in section 3 .

\subsection{The MedGentt project ${ }^{2}$}

The purpose of the MedGentt project, developed by the GENTT research group at the Universitat Jaume I, was to contribute to improving the written information provided to cancer patients in hospitals. For this purpose, we enlisted

2. "Needs analysis and proposal of written information resources for oncology patients", research project supported by the Spanish Ministry of Economy and Competitiveness. 
the participation of healthcare professionals (doctors, nurses and psycho-oncologists) and breast cancer patients at two public hospitals in the Valencian Community (Spain), as well as communication experts (linguists and translators). In this project a mixed research methodology (Patton 1987; Denzin 1989) was employed, in which the data obtained were triangulated using both qualitative and quantitative methods, including readability formulas, questionnaires, interviews and focus groups.

The research study was conducted in four phases. First, through interviews and focus groups we identified the patients' needs for written information in the form of FSPs, as well as their preferences with respect to what information they needed to be provided with and how they wished to receive it. Second, using questionnaires and readability formulas we analysed the quality and comprehensibility of the FSPs provided in the participating hospitals. Third, an improved version of these FSPs was formulated by applying intralingual translation strategies, and tested on a sample of patients by means of questionnaires and focus groups. Finally, on the basis of these results, we produced a final version of the FSPs in Spanish, which was subsequently translated into other languages required in the hospitals: Catalan, French and Romanian. ${ }^{3}$

From the results obtained in the various phases of the project we drew the following conclusions:

- The hospital FSPs were written by nurses, who were trying, on a voluntary basis, to make up for the lack of written materials to supplement the oral information patients receive from the healthcare professionals. The nurses did so by consulting and reformulating texts aimed at specialists, in an intuitive and unsystematic way. Since most of the FSPs explained the side effects of chemotherapy treatments, the texts they reformulated were most often SPCs.

- By using intralingual translation skills the team of translators and linguists was able to correct certain faults in the original FSPs and helped to increase their comprehensibility, defined as a "function of the interaction of the reader with the text" (Garner, Ning \& Francis 2012: 283), which includes both the concept of readibility and that of legibility (García-Izquierdo \& Montalt forthcoming).

3. For further information on the communicative needs of the sample of cancer patients we refer the reader to the article by García-Izquierdo and Muñoz-Miquel (2015). GarcíaIzquierdo and Montalt (forthcoming), in turn, give more details on the methodology used in the comprehensibility analysis of the corpus of FSPs, and Martí (2016) provides a detailed explanation of the process followed to select and validate a readability index. 
- The patients' verdict was that the improved FSPs were more "patient-centred", in that they took their prior knowledge, feelings and information needs into consideration. So having the patients' perspective made it possible to increase the communicative effectiveness of the FSPs, since, according to Garner, Ning and Francis (2012: 293):

The reader constructs the meaning, and the outcome of the communication is his or her behavioural, cognitive and/or affective response. Effectiveness can [be] ascertained on the basis of a comparison of the writer's intended outcome with the actual response.

\subsection{Validated strategies}

As we noted in section 1 , there are several studies that focus specifically on addressing intralingual translation strategies in the medical field, from various points of view. Since these can be consulted in articles such as those of EzpeletaPiorno (2012) and Muñoz-Miquel (2012) or the thesis by Hill-Madsen (2014), among other publications, we shall concentrate here on commenting specifically on those strategies that were validated by the patients taking part in the study aiming at improving the comprehensibility and communicative effectiveness of the FSPs. To be more exact, given that legibility, which concerns the format or visual appearance of texts, such as their length, layout, font size, typeface and other visual elements (DuBay 2004: 3; Clerehan, Buchbinder \& Moodie 2005: 337; Mayor 2008: 11), is less relevant for training, we shall describe the strategies that we applied to improve the linguistic readability and content of the FSPs.

We have grouped these strategies into three categories, according to the rhetorical purposes pursued: those dealing with expert knowledge, those dealing with empathy and those dealing with important or unnecessary information.

\subsubsection{Dealing with expert knowledge}

The FSPs we improved (let us recall that they were produced from reformulations of SPCs) had certain features related to the way information is conveyed in texts aimed at specialists. For example, there was copious use of specialised terminology, nominalisations or complex sentences.

Medical terminology is one of the main barriers to communication between healthcare professionals and patients, and we therefore made considerable use of determinologisation (Askehave \& Zethsen 2000; Montalt \& González 2007; 
Ezpeleta-Piorno 2012; Muñoz-Miquel 2012; Campos 2013; Hill-Madsen 2015; Saiz-Hontangas 2015) of the FSPs, defined as:

[...] a process of recontextualisation and reformulation of specialized terms aiming at making the concepts they designate relevant to and understandable by a lay audience. This process is motivated by specific cognitive, social and communicative needs, and takes place as part of a broader process of recontextualisation and reformulation of discourse. (Montalt forthcoming, apud Montalt \& Shuttleworth 2012: 16)

Determinologisation involves a large number of potential strategies that are covered under this hypernym, such as synonymy, explanation, definition, exemplification, illustration, analogy, comparison, or replacement by a more popular term, among others.

To decrease the technicality (Hill-Madsen 2014, 2015) of the content of the FSP we made particular use of determinologisation by including more popularly-used synonyms but keeping the technical term, putting it in parentheses after the popular equivalent; e.g.: pins and needles (paraesthesia). As well as using synonymy, we defined certain terms with a hypernym (Campos 2013; Hill-Madsen 2015). For example: The medicine you are going to be given as part of your chemotherapy treatment is called Taxol ${ }^{\circledR}$ (placitaxel).

Although omitting the technical terms was considered, some of the patients in the focus groups mentioned that they wanted to be able to identify them, and we therefore decided not to omit any of them. Another strategy that was assessed but finally rejected as unnecessary, given the short length of the FSP, was to include a glossary with definitions or reformulations of the main terms.

Apart from the use of specialised terminology, another issue that proved to be a barrier to understanding the original FSPs was the great predominance of complex grammatical and syntactic forms. To simplify the phrasing, we used the strategy of denominalisation - in other words, converting noun phrases into verbal phrases (Askehave \& Zethsen 2000: 71-73; Montalt \& González 2007) - and made the sentences shorter. Thus, we gave preference to the use of verbal constructions (e.g., inflammation of the mucous membranes of the mouth may occur was reformulated as the mucous membranes of the mouth may become inflamed) and to simple sentences connected by full stops, trying to ensure that each contained a single idea. Moreover, in the improvement process we detected a misuse of punctuation in the original FSPs, which was corrected in the new version. 


\subsubsection{Dealing with empathy}

When the patients compared the two versions of the FSP they commented that the phrasing of the original FSP was rather impersonal and sometimes a bit distant. However, according to the patients, "the improved versions overall sounded more reassuring and comforting, and also more empathic" (GarcíaIzquierdo \& Montalt forthcoming). This was achieved by using a series of strategies, among which the patients particularly appreciated tenor adjustment and personalisation of the information.

For this purpose, we made use of personal pronouns and made the subject of actions explicit, increasing the number of sentences written in the active voice, especially when an action is required of the patient (Askehave $\&$ Zethsen 2000: 71-72; Mayor 2008: 19; Muñoz-Miquel 2014: 199). For example, paracetamol is recommended was replaced by you can take paracetamol and it will be solved by stopping administration by the healthcare staff will stop administering it.

In the light of the patients' views, another strategy we employed to make the text more empathic was to avoid certain words or expressions that might be "hurtful and offensive", as one of them put it (García-Izquierdo \& Montalt forthcoming). A notable example was replacing the lexical items solvent and toxicity with others that sounded less alarming.

Other solutions we implemented were adding sentences in which the patient was urged to speak to the healthcare staff if necessary (by including expressions such as Let staff know if...) and creating a section for them to make a note of questions they wanted to ask on their next visit.

\subsubsection{Dealing with important or unnecessary information}

The information we wanted to convey in the text and the way it was conveyed were handled according to how important that information was to the patient, in the light of the questionnaire and focus group results. So, on the one hand we restructured, expanded and added the information we considered important, and on the other we summarised or omitted unnecessary information (Montalt \& González 2007).

In the case of the textual genre we are dealing with and the subject in question, we observed that the parameters that were important to the patients were the timing, frequency and consequences or severity of side effects, which we arranged in that order. This strategy at the macrotextual level was also followed at the microtextual level.

We also found that anticipating certain effects and their possible solutions made patients feel more secure and more in control of the situation, by avoiding 
premature anxiety and enabling them to be more involved in making informed decisions. So, the definition or explanation of each side effect followed the sequence problem $\rightarrow$ solution: first we explained what the patient might experience and then the causes and the courses of action they could adopt. These could include seeking medical attention and/or recommendations for avoiding or following certain types of behaviour, always accompanied by the relevant medical justification.

By expanding the important information, we mean introducing clarifications that would not be included in a text aimed at specialists, because they would be obvious or unnecessary (Muñoz-Miquel 2014: 202). For example, the patients very much appreciated the drafting of an introduction indicating the purpose of the text and who it was addressed to, so that readers could decide whether the information it contained was of interest to them (Mayor 2008: 13, 15). We also justified the recommendations in a way that avoided mere instruction and included examples to make certain complex or abstract concepts easier to understand. This arose in the case of certain side effects, for which we added explanations of their effect on carrying out everyday activities, so as to encourage readers to take extra care.

Finally, when synthesising the information, we omitted material that we considered unimportant according to our anticipation of patients' needs and interests, particularly certain very complex technical information that had been extracted directly from an SPC without being reformulated, such as information on certain side effects.

\section{Training approach and teaching proposal}

On the basis of our initial premises, set out in the introduction, and the data obtained from validating the intralingual translation strategies we used to improve the linguistic comprehensibility and content of an FSP with a sample of real patients, we designed a teaching proposal aimed at medical translators. For this purpose, we considered three complementary and integrated training approaches:

- Competence-based training (Kelly 2005; Hurtado 2007, 2008).

- A task-based approach (Hurtado 1999, 2007; González 2004).

- The simulation of real professional assignments (Nord 1991; Gouadec 2003).

Translation competence is a complex, multifaceted concept that embraces a number of different facets and has presented a challenge for translator training. 
In the last few decades it has steadily gained acceptance, to the point that it has now become one of the most widely accepted approaches in translator education. Competence is a sophisticated expansion of the notions of ability and qualification, resulting from rapid changes in the organisation of work and planning activities (Grootings 1994) and an increasingly demanding market. Professional action competence is thus the sum of the competences that are essential to carrying out a professional task satisfactorily (Echeverría 2002). Within this general framework, numerous scholars have devoted their attention to translation competence, including Kiraly (2000), Schäffner and Adab (2000), Kelly (2002, 2005, 2007), PACTE (2003, 2009), Pym (2003), Göpferich (2009), among others. Pursuing this line, Lasnier (2001) has identified a series of interrelated principles inherent in competence-based training (CBT); the most relevant for the purposes of our study are the following:

- It is an integrated model which reconciles different approaches and brings together knowledge, skills and values (Hurtado 2007; Kelly 2007).

- It allows for teaching methods such as problem-based, task-oriented and project-oriented learning (Hurtado 2007; Galán-Mañas \& Hurtado 2015).

- It takes professional practice into account and allows for operationalising competences according to areas of specialisation and/or professional profiles (Calvo 2010; Galán-Mañas \& Hurtado 2015).

The GENTT group, concerned with specialised translation, has explored the relationship between textual genres from specialised fields and the acquisition of translation competence (Montalt, Ezpeleta-Piorno \& García-Izquierdo 2008); more specifically, Muñoz-Miquel (2014, 2016a) has focused on the particularities of medical translator competence. Through an empirical study carried out with professional translators working in the Spanish-English language combination, this author has defined and validated five competence clusters specific to medical translators and essential to their training: the textual and communicative cluster, the documentary cluster, the thematic and terminological cluster, the socio-professional and interpersonal cluster and the cultural cluster.

As already noted, translation tasks are one of the possible tools that can be used to operationalise competences within the framework of CBT. Numerous studies have proposed task-based learning as one of the most suitable means of achieving effective CBT (Mulcahy 2000; González 2004; Parsons, Caylor 
\& Simmons 2005; Kelly 2007). In our proposal, we distinguish between pre-translation tasks, understood as "concrete and brief exercises that help to practice specific points [...] leading along the same path towards the same end, or [as] a chain of activities with the same global aim and a final product" (González 2004: 22-23), and final tasks, which "are comprised of integration tasks, which activate the components of a competence" (Hurtado 2007: 180). Along the same lines as our proposal, Nord (1991, 1997, 2009), who is concerned with issues of pedagogical progression, argues that simpler analytical and declarative tasks should precede more complex procedural projects.

Following the recommendations of Kiraly (2000), Galán-Mañas and Hurtado (2015), and more specifically Gouadec (2007), Kelly (2007) and Ramos and Meseguer (2015), among others, the skills developed in the pre-translation tasks proposed, as shown in section 3.1, have been integrated and packaged into a final task that simulates a real professional assignment. We are training not just individuals capable of integrating theoretical knowledge, values and attitudes, but also competent professionals in their fields of expertise. However, the competences directly related to professional practice are scarcely addressed through specific tasks (Gil et al. 2007 apud Ramos \& Meseguer 2015). Recreating the professional environment in pedagogical settings helps narrow the gap between higher education and the professional world, allows teachers to monitor (control and guide) the acquisition of the students' first professional experiences and fosters students' self-learning, motivation and interest.

\subsection{Teaching proposal}

As already indicated, our teaching proposal is based primarily on the empirical study we carried out, but it also arises from reflections stimulated by our experience as teachers for the Master's Degree in Medical and Healthcare Translation at the Universitat Jaume I. The tasks we present are open units of work, representative of translation practice, that could be used as examples for constructing teaching units and for curriculum design of postgraduate courses and master's degrees in medical translation.

The general methodological objective is dealing with specialised knowledge, that is, for would-be medical translators to acquire the ability to reformulate specialised knowledge to meet patients' expectations and needs. To achieve this, we propose a series of tasks as an example and a possible model, that work on various aspects of the interventions performed on texts aimed at specialists 
(health professionals) to turn them into texts aimed at non-experts (patients, support persons, etc.).

The specific competences to be worked on belong mainly to the thematic/ terminological and textual/communicative competence clusters proposed by Muñoz-Miquel (2014) for medical translators. The thematic and terminological cluster covers acquiring basic medical knowledge (of anatomy, general medicine, physiology, pharmacology, etc.) and fostering the ability to acquire it ad hoc according to the thematic problems that arise in translations. This serves to stimulate students' terminological competence and their acquisition of the phraseology and writing style characteristic of specialists, as well as to improve their understanding of the original texts.

The textual and communicative cluster includes communicative and textual competences of fundamental importance in the professional context, such as capacity for comprehension, textual analysis, writing in the target language, adapting to specific conventions and purposes, etc. These skills can be acquired by training in the textual genres, of both a popularising and a specialist nature, that are most often found in medical and healthcare environments.

Another activity that is also part of this competence cluster is carrying out genre shifts or intralingual translations, both intra- and interlingually. As we have already pointed out in section 1, intralingual translation assignments are not as common as those for equifunctional translation, but given the paradigm shift in the doctor-patient relationship and the growing demand from patients for verified and reliable but accessible information, we presume that there will be an increasing demand for this type of task. The results obtained in the study by Muñoz-Miquel $(2014,2016 a)$, with respect to trends in professional development and the emergence of new professional profiles in the field of medical translation, point in this direction.

It should be pointed out that, although our empirical study (described in section 2) was carried out in a Spanish-speaking context, our intralingual translation strategies coincide with those identified in the literature for medical texts written in English (see sections 1 and 2.2). Nevertheless, it should be emphasised that this proposal is designed to work specifically on the strategies that were validated in the case study, and that were considered most useful for proper reception of specialised medical information. These strategies, which will be practised in the successive pre-translation tasks and combined in a final task, will lead to the ultimate learning outcome: being capable of using the appropriate skills to carry out an intralingual translation of a specialised original text into a target text for patients. In this sense, as González (2004: 
207) proposes, "both procedural (know how) and declarative (know what) knowledge are practised and explored".

\subsubsection{Pre-translation tasks}

The pre-translation tasks are organised in three blocks and pursue a range of specific learning objectives:

I. Dealing with expert knowledge

Task 1. Becoming familiarised with determinologisation strategies

Task 2. Dealing with terminological doublets

Task 3. Identifying and defining key terms and/or concepts

II. Dealing with empathy: personalising communication strategies and tenor adjustment

Task 4. Personalising specialised discourse

III. Dealing with different textual genres

Task 5. Comparing different textual genres

\subsubsection{Dealing with expert knowledge}

When the focus of communication of medical knowledge shifts from specialists to the general public, terminology, which is a quick, clear and precise way of transmitting information for the specialist, may hinder comprehension for the lay reader. Thus, determinologisation strategies, such as identifying and using specialised terms or lay terms properly, or choosing the appropriate words depending on register, are a requirement for medical translators (EzpeletaPiorno 2012: 180). 


\section{Task 1}

1. Read the following articles on determinologisation strategies:

- Askehave, Inger \& Karen K. Zethsen. (2000) "Medical texts made simple-dream or reality?" Hermes, Journal of Linguistics 25, pp. 63-74.

- Campos Andrés, Olga. (2013) "Procedimientos de desterminologización, traducción y redacción de guías para pacientes." Panace@: Revista de Medicina, Lenguaje y Traducción 14:37, pp. 48-52.

- Hill-Madsen, Aage. (2015) "Lexical Strategies in Intralingual Translation between Registers." Hermes, 54, pp. 85-105.

2. Describe the strategies applied in the following excerpts:

\begin{tabular}{|l|l|}
\hline \multicolumn{1}{|c|}{ Text excerpts } & \multicolumn{1}{|c|}{$\begin{array}{c}\text { Strategies used to } \\
\text { determinologise the text }\end{array}$} \\
\hline $\begin{array}{l}\text { 1. [...] in patients with signs of cerebral or cardiac } \\
\text { ischemia (impaired blood circulation in the brain or } \\
\text { heart vessels) }\end{array}$ & \\
\hline $\begin{array}{l}\text { 2. Numbness or weakness in limbs (peripheral } \\
\text { neuropathy) }\end{array}$ & \\
\hline 3. Diphenylhydantoin (a drug used to treat epilepsy) & \\
\hline 4. Cytotoxics (also called chemotherapy) & \\
\hline $\begin{array}{l}\text { 5. People commonly use nonsteroidal anti-inflammatory } \\
\text { drugs (NSAIDs) to relieve pain. Examples of NSAIDs } \\
\text { include aspirin and ibuprofen (Advil or Motrin) }\end{array}$ & \\
\hline
\end{tabular}

Table 1. Task 1: Becoming familiarised with determinologisation strategies

In task 1, students first read some articles on the topic to become familiarised with determinologisation strategies described by scholars and then identify which strategies are applied in a series of examples extracted from real texts: patient information leaflets (PILs) and FSPs. As we can see, all the proposed examples retain the specialised medical term, reflecting the preferences of the patients who took part in the case study.

Through this activity, students familiarise themselves with a range of determinologisation strategies, such as using a definition, a popular term, a hypernym, a synonym, an example, an explanation, etc. Moreover, they also become familiarised with medical terminology and concepts, so the activity also promotes acquisition of competences related to the thematic and terminological competence cluster. 
Intralingual translation in healthcare settings: strategies and proposals for medical... 193

\section{Task 2}

Look for the specialised term or the popular term, as appropriate:

\begin{tabular}{|l|l|}
\hline \multicolumn{1}{|c|}{ Specialised term } & \multicolumn{1}{c|}{ Popular term } \\
\hline & Bleeding \\
\hline Thrombophlebitis & \\
\hline Glucose & Nettle rash \\
\hline Hypersensitive & \\
\hline & \\
\hline Endocrine disorder & Severe headache \\
\hline
\end{tabular}

Table 2. Task 2: Dealing with terminological doublets

In task 2, students familiarise themselves with specialised terms and the corresponding popular terms. This activity is especially important when working with non-Romance languages such as English and can be very useful for preparing students to deal with intralingual translations. Since the students themselves have to look for the equivalents in each case, they also work on competences related to the documentary cluster, which involves knowing the main sources of medical documentation and their uses and developing advanced search strategies.

\section{Task 3}

1. Read the following excerpt from an SPC (summary of product characteristics) and select the terms, expressions and concepts you think a patient will not understand.

2. Create a glossary with definitions for a lay reader.

Significant hypersensitivity reactions, as characterised by dyspnoea and hypotension requiring treatment, angioedema, and generalised urticaria have occurred in $<1 \%$ of patients receiving paclitaxel after adequate premedication. These reactions are probably histamine-mediated. In the case of severe hypersensitivity reactions, paclitaxel infusion should be discontinued immediately, symptomatic therapy should be initiated and the patient should not be rechallenged with paclitaxel.

Table 3. Task 3: Identifying and defining key terms and/or concepts

In task 3, students familiarise themselves with the vocabulary characteristics of specialised texts such as the SPC from which the proposed extract is taken. In addition, they make a cognitive effort in identifying the terms, expressions 
and concepts that present special difficulties. In this task, as well as working with the thematic/terminological and textual/ communicative competence clusters, students also practice the documentary cluster, as they will have to perform advanced search tasks and be capable of efficiently generating reference resources such as glossaries.

\subsubsection{Dealing with empathy: personalising communication strategies and tenor adjustment}

As we saw in the case study, a series of strategies is necessary to make texts more approachable and empathic for the target reader. To achieve this, the tenor needs to be adjusted to achieve more personalised communication.

\begin{tabular}{|l|l|}
\hline \multicolumn{2}{|l|}{ Task 4} \\
\hline \multicolumn{1}{|c|}{ Impersonal } & \\
\hline $\begin{array}{l}\text { Paclitaxel can reduce the number of blood } \\
\text { transfusions needed. }\end{array}$ & Personal \\
\hline $\begin{array}{l}\text { The usual dose is one tablet of Paclitaxel to be taken } \\
\text { once a day. }\end{array}$ & \\
\hline $\begin{array}{l}\text { The tablet can be taken with or without food and } \\
\text { should be swallowed whole with a glass of water or } \\
\text { another liquid. }\end{array}$ & \\
\hline
\end{tabular}

Table 4. Task 4: Personalising specialised discourse

In task 4, students familiarise themselves with the syntax characteristics of specialised texts. The intention is that they should reflect on the differences of register required in texts aimed at lay readers compared with those of a specialised nature. So, they are asked to try to make the text accessible to lay readers and decrease the degree of formality in various fragments of an SPC by making use of strategies such as introducing personal pronouns, using active instead of passive constructions, etc.

\subsubsection{Dealing with different textual genres}

As Ezpeleta-Piorno (2012: 139) has stated, acquiring competence in textual genres can be considered an effective means of acquiring the abilities needed by medical translators, as it facilitates their socialisation as communicative agents in medical professional sectors. 


\section{Task 5}

Analyse and compare the SPC and PIL for Paclitaxel:

1. What is the purpose of each text?

- Who are the senders and receivers of each text? What are their needs?

2. Identify the information in the SPC that appears in the PIL and reflect on:

- The reasons for selecting those pieces of information

- The strategies used to reformulate information

Reading proposed: Ezpeleta-Piorno, Pilar. (2012) "An example of genre shift in the medicinal product information genre system." Linguistica Antverpiensia, New Series Themes in Translation Studies 11, pp. 167-187.

Table 5. Task 5: Comparing different textual genres

In task 5, students are asked to compare two interrelated genres: the SPC, a document which contains the essential information for healthcare professionals on how to use a medicinal product safely and effectively, and the PIL, which is the leaflet, addressed to patients, included in the pack with the medicine. We have chosen these genres because we find them particularly interesting for our teaching purposes. PILs are composed from SPCs in an intralingual translation process in which changes in rhetorical purpose and audience inevitably affect the texture and manner of re-presentation of the target text, the PIL.

In this task students familiarise themselves with the macro- and micro-characteristics of both genres, recognise various strategies they have practised in previous tasks and learn other strategies that are important in intergeneric translation, such as selection, omission and/or reorganisation of information.

Students also have to make the effort to try to understand that intralingual translation is used to bridge the gap between the patient's right to know and the patient's ability to understand, and can serve to ensure continuity of communication between communities with different levels of expertise.

\subsubsection{Final task: a real professional assignment}

The learning objective of the final task is for students to combine all the skills developed in the pre-translation tasks and put them into practice comprehensively, by carrying out a piece of work corresponding to what a real professional intralingual translation assignment would be like. The competences brought into play are mainly those belonging to the textual/communicative and thematic/terminological clusters, although those in the documentary cluster are also involved. Given that this task simulates a real professional assignment, the students also practise strategic skills related to the socio-professional competence cluster proposed by Muñoz-Miquel (2014). 


\section{Final task}

A private hospital in the UK wants to write a FSP on adverse effects of the drug paclitaxel and gives you its SPC (written in English) as reference material:

1. Write a FSP (about 700-900 words) in English based on the SPC provided.

2. Briefly justify your translation decisions (using up to 500 words).

Table 6. Final task: Intralingual translation

Through this task the students familiarise themselves with two working genres, the SPC and the FSP, in their textual and communicative aspects. They also explore the operations that take place between the specialised genre and the lay-friendly one.

Although the two genres deal with the same topic, they fulfil different functions and cover specific reader needs, and students therefore need to reflect on how they are interrelated in referential and functional terms. The target text is dependent on the original text as far as communication is concerned, but will have to be written according to different processes of rhetorical composition, with a decreasing degree of specialisation and formality. In order to put these changes into effect, the strategies practised to deal with expert knowledge and terminology, empathy and different registers, as well as different genres will have to be implemented. If the development of interlingual translation skills is also pursued, students can be asked to translate the SPC in English into a FSP in their target language.

\section{Conclusions and future lines of research}

In this article we have presented a teaching proposal designed to promote the acquisition of intralingual translation skills by medical translators-in-training. The novel feature of this proposal is that it focuses on practising strategies that are not usually included in translator training programmes and reflect the preferences of target readers with respect to how they want to receive the information, and whose effectiveness has been validated in a research project conducted with a group of real patients. It is therefore a proposal that goes beyond the purely descriptive studies that characterise the still incipient field of intralingual translation research, as it is based on the results of a case study in a real context.

Given the dearth of proposals for preparing future medical translators to respond to the growing need for intralingual translations that facilitate the transmission of medical knowledge to patients and the general public, we 
consider that this article contributes to filling a gap in the training of versatile medical translators, capable of taking on this emerging professional activity. In addition, the proposal serves to foster not only the acquisition of skills related to intralingual translation, but also other competences traditionally linked to "translation proper", such as thematic, documentary and terminological competences.

At this point, we should acknowledge the limitations of the study. Firstly, the strategies in which we propose that translators should be trained have been applied to a single genre, the FSP, and validated in a context and with a sample of patients of a very specific nature and limited size. To obtain more conclusive results on the effectiveness of the strategies used, they should also be applied to other texts aimed at patients and tested with a larger and more varied sample of potential users. Secondly, this is a proposal for specific tasks that represents only a basis on which to formulate teaching units within specific curricular proposals. We need to take other issues into account, such as the profile and prior knowledge of the students, the intended mode of assessment, the educational context in which it is to be implemented, etc. (Kelly 2005), issues that have not been taken into account in this article. Finally, we should add that the tasks sketched out here are designed for translators whose working languages are English and Spanish (the language in which we validated the strategies with the patients). In order to be able to apply it to other languages one would first have to take account of their socio-linguistic specificities.

In our future work, as well as completing the teaching proposal and applying it to a specific training context, we would like to analyse the usefulness of intralingual translation activities for training medical professionals in communication skills. Given the present lack of training of students of medicine and related sciences in techniques for communicating with patients (Bellés-Fortuño $\&$ Molés-Cases 2017), the GENTT group is currently conducting two research projects (see footnote 1 ) designed to produce materials that will contribute to meeting this need. These projects are therefore the ideal framework for testing intralingual translation as a training tool to achieve more effective doctor-patient communication, and hence to raise the profile of Translation Studies as a discipline capable of making a significant contribution in other fields of study in which communication needs to be improved. 


\section{References}

Albin, Verónica. (1998) "Translating and formatting medical texts for patients with low literacy skills.” In: Fischbach, Henry (ed.) 1998. Translation and Medicine. Amsterdam: John Benjamins, pp. 117-129.

ARrighi, Emilia; Albert J. Jovell \& María Dolores Navarro. (2010) "El valor terapéutico en oncología. La perspectiva de Pacientes, familiares y profesionales." Psicooncología 7:2-3, pp. 363-374.

ASKEHAVE, Inger \& Karen K. Zethsen. (2000) "Medical texts made simple-dream or reality?" Hermes, Journal of Linguistics 25, pp. 63-74.

ASKEHAVE, Inger \& Karen K. Zethsen. (2001) "Inter-generic and inter-linguistic translation of patient package inserts." In: Mayer, Felix (ed.) 2001. Language for special purposes: Perspectives for the new millennium. Tübingen: Gunter Narr, pp. 882-887.

ASKEHAVE, Inger \& Karen K. Zethsen. (2002) "Translating for Laymen." Perspectives: Studies in Translatology 10:1, pp. 15-29.

Askehave, Inger \& Peter Kastberg. (2001) "Intergeneric Derivation: On the Genealogy of an LSP Text.” Text \& Talk 21:4: pp. 489-513.

BELlÉS-Fortuño, Begoña \& Teresa Molés-Cases. (2017) "El aprendizaje de la competencia comunicativa aplicada al contexto clínico: un estudio piloto." Paper presented at the Segundo Congreso Internacional Ciencia y Traducción "Puentes interdisciplinares y difusión del conocimiento científico", Universidad de Córdoba, April 5-7.

Calvo Encinas, Elisa. (2010) Análisis curricular de los estudios de Traducción e Interpretación en España. Perspectiva del estudiantado. Granada: Universidad de Granada. PhD thesis.

CAMPOS ANDrÉs, Olga. (2013) "Procedimientos de desterminologización, traducción y redacción de guías para pacientes." Panace@: Revista de Medicina, Lenguaje y Traducción 14:37, pp. 48-52. Electronic version: <http://www. medtrad.org/panacea/IndiceGeneral/n37-tradyterm-OCamposAndres.pdf>

Clerehan, Rosemary; Rachelle Buchbinder \& Jane Moodie. (2005) "A linguistic framework for assessing the quality of written patient information: its use in assessing methotrexate information for rheumatoid arthritis." Health Education Research 20:3, pp. 334-344. Electronic version: <https://doi.org/10.1093/her/ cyg123>

DenzIn, Norman K. (1989) The Research Act. A Theoretical Introduction to Sociological Methods. Englewood Cliffs: Prentice Hall.

DuBAy, William H. (2004) The Principles of Readability. Impact Information. Electronic version: <https://eric.ed.gov/?id=ED490073> 
ECHEVERRÍA, Benito. (2002) "Gestión de la competencia de acción profesional." Revista de Investigación Educativa 20:1, pp. 7-43. Electronic version: <http:// revistas.um.es/rie/article/view/97411>

EZPELETA-PIORNO, Pilar. (2012) "An example of genre shift in the medicinal product information genre system." Linguistica Antverpiensia, New Series - Themes in Translation Studies 11, pp. 167-187. Electronic version: <https://lans.ua.ac.be/ index.php/LANS-TTS/issue/view/15>

GaLÁN-MAÑAS, Anabel \& Amparo Hurtado Albir. (2015) "Competence assessment procedures in translator training." The Interpreter and Translator Trainer 9:1, pp. 63-82.

GARCíA-IZQUiERdo, Isabel \& Ana Muñoz-Miquel. (2015) "Los folletos de información oncológica en contextos hospitalarios: la perspectiva de pacientes y profesionales sanitarios." Panace@: Revista de Medicina, Lenguaje y Traducción 16:42. Electronic version: <http://www.medtrad.org/panacea/IndiceGeneral/ n42_tribuna-EGIzquierdoAMMiquel.pdf>

GARCÍA-IZQUIERDO, Isabel \& Vicent Montalt Resurrecció. (2013) "Equigeneric and Intergeneric Translation in Patient-Centred Care." Hermes - Journal of Language and Communication in Business 51, pp. 39-51. Electronic version: <http://download2.hermes.asb.dk/archive/download/Hermes-51-4-izquierdo\%20\&\%20 montalt.pdf>

GARCÍA-IZQUIERDO, Isabel \& Vicent Montalt Resurrecció. (forthcoming) "Understanding and enhancing comprehensibility in texts for patients in an institutional health care context in Spain: A mixed method analysis." Revista Española de Lingüística Aplicada.

GARNER, Mark; Zhenye Ning \& Jill Francis. (2012) "A framework for the evaluation of patient information leaflets." Health Expectations 15, pp. 283-294.

GOnZÁlez DAVIES, María. (2004) Multiple voices in the translation classroom: Activities, tasks and projects. Amsterdam: John Benjamins.

GÖPFERICH, Susanne. (2009) "Towards a model of translation competence and its acquisition: the longitudinal study TransComp." In: Göpferich, Susanne; Arnt Lykke Jakobsen \& Inger M. Mess (eds.) 2009. Behind the mind: Methods, models and results in translation process research. Denmark: Samfundslitteratur, pp. 11-37.

GOUADEC, Daniel. (2003) "Notes on translator training (replies to a questionnaire)." In: Pym, Anthony (ed.) 2003. Innovation and E-Learning in Translator Training. Tarragona: Universitat Rovira i Virgili. Electronic version: <http://isg. urv.es/library/papers/innovation_book.pdf>

GOUADEC, Daniel. (2007) Translation as a Profession. Amsterdam \& Philadelphia: John Benjamins.

GroOtings, Peter. (1994) "De la cualificación a la competencia: ¿de qué se habla?" Revista Europea de Formación Profesional 1, pp. 5-7. 
Hill-Madsen, Aage. (2014) Derivation and Transformation: Strategies in Layoriented Intralingual Translation. Aarhus: Aarhus University. Unpublished PhD thesis. Electronic version: <http://pure.au.dk/portal/files/73870680/ Dissertation_AageHM_final.pdf>

Hill-Madsen, Aage. (2015) "Lexical Strategies in Intralingual Translation between Registers.” Hermes 54, pp. 85-105. Electronic version: <https://tidsskrift.dk/ index.php/her/article/view/22949/20059>

HurTAdo Albir, Amparo. (1999) "Objetivos de aprendizaje y metodología en la formación de traductores e intérpretes.” In: Hurtado Albir, Amparo (ed.) 1999. Enseñar a traducir. Madrid: Edelsa, pp. 8-58.

HurTAdo Albir, Amparo. (2007) "Competence-based curriculum design for training translators." The Interpreter and Translator Trainer 1:2, pp. 163-195.

Hurtado Albir, Amparo. (2008) "Compétence en traduction et formation par compétences." TTR: traduction, terminologie, rédaction 21:1, pp. 17-64.

JAKOBSON, Roman. (2000 [1959]) "On linguistic aspects of translation." In: Venuti, Lawrence (ed.) 2000. The Translation Studies Reader. London \& New York: Routledge, pp. 113-118.

JENSEN, Matilde N. \& Karen K. Zethsen (2012) "Translation of patient information leaflets - Trained translators and pharmacists-cum-translators: A comparison." Linguistica Antverpiensia New Series - Themes in Translation Studies 11, pp. 31-49. Electronic version: <https://lans-tts.uantwerpen.be/index.php/ LANS-TTS/article/view/295>

KELLY, Dorothy. (2002) "Un modelo de competencia traductora: bases para el diseño curricular." Puentes 1, pp. 9-20.

Kelly, Dorothy. (2005) A Handbook for Translator Trainers. A Guide to Reflective Practice. Manchester: St. Jerome.

KELly, Dorothy. (2007) "Translator competence contextualized. Translator training in the framework of higher education reform: In search of alignment in curricular design." In: Kenny, Dorothy \& Kyongjoo Ryou (eds.) 2007. Across Boundaries. International Perspectives on Translation Studies. Newcastle: Cambridge Scholars, pp. 128-142.

KIM, Mira. (2012) "Research on translator and interpreter education." In: Millán, Carmen \& Francesca Bartrina (eds.) 2012. The Routledge handbook of translation studies. Routledge, pp. 102-116.

KIRAly, Donald. (2000) A Social Constructivist Approach to Translator Education: Empowerment from Theory to Practice. Manchester: St. Jerome.

LASNIER, François. (2001) "Un modèle intégré pour l'apprentissage d'une competence." Pédagogie collégiale 15:1), pp. 28-33.

MARTí FERRIOL, José Luis. (2016) "Selection and validation of a measurement instrument for readability calculations in patient information leaflets for 
oncological patients in Spain." Journal of Research Design and Statistics 3:1, pp. 110-125.

Mayor Serrano, Blanca. (2008) Cómo elaborar folletos de salud destinados a los pacientes. Barcelona: Fundación Dr. Antonio Esteve. Electronic version: <http:// www.esteve.org/?wpdmact=process\& $\&$ did=NDQ3LmhvdGxpbms=>

Montalt Resurrecció, Vicent \& María González Davies. (2007) Medical Translation Step by Step. Learning by Drafting. Manchester: St Jerome.

Montalt ReSURRECCIÓ, Vicent \& Mark Shuttleworth (2012). "Research in translation and knowledge mediation in medical and healthcare settings." Linguistica Antverpiensia New Series - Themes in Translation Studies 11, pp. 9-30. Electronic version: <https://lans-tts.uantwerpen.be/index.php/LANS-TTS/ article/view/294/184>

Montalt ResurReCció, Vicent; Pilar Ezpeleta \& Isabel García-Izquierdo. (2008) "The acquisition of translation competence through textual genre." Translation Journal 12:4. Electronic version: <http://repositori.uji.es/xmlui/bitstream/ handle/10234/25245/30807.pdf?sequence=l>

MulCAHY, Dianne \& Pauline James. (2000) "Evaluating the contribution of competency-based training: An enterprise perspective." International Journal of Training and Development 4, pp. 160-175.

Muñoz-Miquel, Ana. (2012) "From the original article to the summary for patients: Reformulation procedures in intralingual translation." Linguistica Antverpiensia, New Series - Themes in Translation Studies 11, pp. 187-206. Electronic version: <https://lans.ua.ac.be/index.php/LANS-TTS/issue/view/15> MuÑoz-Miquel, Ana. (2014) El perfil del traductor medico: análisis y descripción de competencias específicas para su formación. Castellón de la Plana: Universitat Jaume I. Unpublished PhD thesis. Electronic version: <http://hdl.handle. net/10803/321365>

MuÑOZ-MiQuEL, Ana. (2016a) "Bridging the Gap between Professional Practice and University Training through Socio-professional Research: The Case of Medical Translation.” In: Martín de León, Celia \& Víctor González-Ruiz (eds.) 2016. From the Lab to the Classroom and Back Again: Perspectives on Translation and Interpreting Training. Frankfurt am Main: Peter Lang, pp. 257-294.

MuÑoz-Miquel, Ana. (2016b) "La enseñanza de la traducción médica en los programas de posgrado españoles: ¿qué competencias se enseña a los estudiantes." Sendebar 27, pp. 1-28.

NAVArRo Rubio, María Dolores. (2014) "Pacientes implicados: participación del paciente en la toma de decisiones." Revista trimestral de la Fundación de las Cajas de Ahorros (FUNCAS), Papeles de economía española 142.

Nord, Christiane. (1991) Text Analysis in Translation. Theory, Methodology, and Didactic Application of a Model for Translation-Oriented Text Analysis. Amsterdam: Rodopi. 
Nord, Christiane. (1997) A functional typology of translations. Amsterdam \& Philadelphia: John Benjamins.

NORD, Christiane. (2009) "El funcionalismo en la enseñanza de traducción." Mutatis Mutandis 2:2. pp. 209-243.

PARSONS, Charles K.; Evan Caylor \& Harold S. Simmons. (2005) "Cooperative Education Work Assignments: The role of Organizational and Individual Factors in Enhancing ABET Competencies and Co-op Workplace Well-Being." Journal of Engineering Education 94:3, pp. 309-316.

PACTE. (2003) "Building a translation competence model." In: Alves, Fabio (ed.) 2003. Triangulating Translation: Perspectives in Process Oriented Research. Amsterdam \& Philadelphia: John Benjamins, pp. 43-66.

PACTE. (2009) "Results of the validation of the PACTE translation competence model: Acceptability and decision making." Across Languages and Cultures 10:2, pp. 207-230.

PATton, Michael. (1987) Qualitative Evaluation Methods. Beverly Hills: Sage.

PYM, Anthony. (2003) "Redefining translation competence in an electronic age. In defence of a minimalist approach." Meta 48:4, pp. 481-497.

RAMOS, Marina \& Purificación Meseguer. (2015) "Learning through real assignments in the audiovisual translation classroom." Current Trends in Translation Teaching and Learning E 2, pp. 72-96. Electronic version: <http://www.cttl. org/uploads/5/2/4/3/5243866/chapter_3_learningthroughrealassignments.pdf>

SAIZ-HONTANGAS, Paula. (2015) La personalización de las guías para pacientes: una primera aproximación desde la perspectiva del nivel de activación del paciente. Castellón de la Plana: Universitat Jaume I. Unpublished Master's dissertation.

SCHÄFFNER, Christina. (1999) "Globalisation, Communication, Translation." Current Issues in Language and Society 6:2, pp. 93-102.

SCHÄFFNER, Christina \& Beverly Adab. (2000) Developing Translation Competence. Amsterdam \& Philadephia: John Benjamins.

ZethSEN, Karen K. (2007) "Beyond Translation Proper-Extending the Field of Translation Studies." TTR: traduction, terminologie, redaction 20:1, pp. 281-308. Electronic version: <https://www.erudit.org/revue/ttr/2007/v20/n1/018506ar. html>

Zethsen, Karen K. (2009) "Intralingual Translation: An Attempt at Description." Meta 54:4, pp. 795-812. Electronic version: <http://id.erudit.org/ iderudit/038904ar>

ZETHSEN, Karen K. \& Aage Hill-Madsen. (2016) "Intralingual Translation and Its Place within Translation Studies - A Theoretical Discussion." Meta 61:3, pp. 692-708. Electronic version: <http://id.erudit.org/iderudit/1039225ar> 


\section{NOTAS BIOGRÁFICAS / BIONOTES}

Ana MuÑoz-Miquel es Profesora Ayudante Doctora en el Departamento de Traducción y Comunicación de la Universitat Jaume I (UJI), donde imparte docencia en el Grado en Traducción e Interpretación y el Máster en Traducción Médico-Sanitaria. Su tesis, centrada en el perfil y las competencias del traductor médico, obtuvo el Premio Extraordinario de Doctorado de la UJI y el Premio a la Mejor Tesis del Bienio que otorga la Asociación Ibérica de Estudios de Traducción e Interpretación. Durante su trayectoria, ha trabajado como traductora autónoma y ha sido investigadora predoctoral y postdoctoral en la UJI. Actualmente, es miembro del grupo de investigación GENTT (UJI) y colaboradora del grupo CiTrans (Universitat de València). Entre sus principales líneas de trabajo destacan la traducción médica, la formación por competencias y la comunicación dirigida a pacientes, temas sobre los que ha publicado en revistas como Target, Linguistica Antverpiensia, Trans, Sendebar, JoSTrans, HermēneusoPanace@.

Pilar EZPELETA-Piorno es profesora Titular y Directora del Departamento de Traducción y Comunicación de la Universitat Jaume I, donde imparte docencia en Traducción médica y Traducción literaria y teatral. Sus principales líneas de investigación son los géneros textuales para la traducción y la traducción literaria y teatral. Forma parte de los grupos de investigación GENTT-Géneros Textuales para la Traducción y Lenguas y Culturas Europeas y Nuevos Lenguajes Literarios y Audiovisuales de la Universitat Jaume I. Ha impartido e imparte docencia en diversos másteres universitarios en la Universitat Jaume I, la Universitat de València y la Universidad de Málaga. También fue coordinadora del Máster en Traducción y Comunicación de la Fundación Shakespeare de España. Es autora de trabajos entre los que destaca Teatro y Traducción (Cátedra, Madrid 2008). Asimismo, es coeditora de las ediciones bilingües de Ricardo II, Coriolano y La Comedia de los Errores para la colección Letras Universales de la editorial Cátedra.

PAUla SAIZ-HONTANGAS es graduada en Traducción e Interpretación por la Universitat Jaume I y ha cursado el máster en Traducción Médico-Sanitaria de la misma universidad. Actualmente está realizando su doctorado sobre la comprensibilidad de la información escrita destinada a pacientes y es miembro del grupo de investigación GENTT. Sus áreas de interés son la traducción especializada, la comunicación clínica y la divulgación del conocimiento especializado. 
ANA MuÑOZ-Miquel is a Lecturer in the Translation and Communication Department at the Universitat Jaume I (UJI), where she teaches for the Degree in Translation and Interpreting and the Master's Degree in Medical and Healthcare Translation. Her doctoral thesis, on the profile and competences of medical translators, won the Special Doctorate Award at the UJI and the Biennial Best Thesis Award granted by the Iberian Association for Translation and Interpreting Studies. During her career she has worked as a freelance translator and has been a pre-doctoral and post-doctoral researcher at the UJI. She is currently a member of the GENTT research group (UJI) and a collaborator in the CiTrans group (Universitat de València). Her research interests prominently include medical translation, competence-based training and communication aimed at patients, and she has published on these subject in journals such as Target, Linguistica Antverpiensia, Trans, Sendebar, JoSTrans, Hermēneus and Panace@.

Pilar EZPELETA-PiORNO is a Senior Lecturer in translation at the Universitat Jaume I (UJI), where she is Head of the Translation and Communication Department. Her main research interests and publications deal with textual genres for translation, specialised translation, and literary and theatre translation. She is now engaged in the research teams Textual Genres for Translation (GENTT) and European Languages and Cultures and New Literary and Audiovisual Languages. She has taught for several master's degrees in Medical Translation (UJI), in Translation and Interpretation Research (UJI), in Creative and Humanistic Translation (Universitat de València) and in Literary and Humanistic Translation (University of Málaga). She was also coordinator of the Master's degree in Translation and Communication of the Shakespeare Foundation of Spain. Her critical works include Teatro y traducción (2008), among others. She has also coedited and translated Richard II, Coriolanus and The Comedy of Errors into Spanish for Cátedra ediciones.

PAUla SAIZ-HONTANGAS graduated in Translation and Interpreting at the Universitat Jaume I and took the Master's Degree in Medical and Healthcare Translation at the same university. She is currently working on her doctorate on the comprehensibility of written information aimed at patients and is a member of the GENTT research group. Her areas of interest are specialised translation, clinical communication and popularisation of specialised knowledge. 